\title{
TEORIA DO ESTRANHAMENTO
}

Nogueira, Antônio; mestrando em Design; Universidade Federal de Pernambuco art.toninogueira@gmail.com

Resumo: Este artigo pretende sistematizar a noção de estranhamento como técnica utilizada nas artes visuais. Serão adotadas, para isso, a teoria do inquietante (FREUD, 1919), como noção geral de Estranhamento, além do conceito de singularização do objeto de (CHKLOVSKI, 1917), como a primeira formulação do estranhamento no campo das artes. Complementando o embasamento teórico, este trabalho mobilizará também a teoria da atualização (MUKAROVSKY, 1967), todos os conceitos provenientes da teoria da literatura, exceto o conceito de Freud. Teoricamente, algumas questões acerca dos estilos artísticos cubismo, dadá, surrealismo e a arte contemporânea também serão vistas, considerando-os como exemplos práticos do uso da técnica de estranhamento. Esse referencial teórico compõe a dissertação $O$ Estranhamento na arte da Oficina Guaianases (NOGUEIRA, 2014).

Palavras-chave: Estranhamento, Desautomatização, Inquietante, Singularização do objeto.

Abstract: This article aims to systematize the notion of Strangeness as a technique used in the visual arts. For this, will be adopted: the theory of Disquieting (FREUD, 1919), as a general notion of Strangeness; and the concept of singularity of the object (CHKLOVSKI, 1917), as the first formulation of strangeness in the arts, complemented by the theory of Update (MUKAROVSKY, 1967) all concepts from the theory of literature, except the concept of Freud. Also seen are some theoretical issues concerning artistic styles such as Cubism, Dada, Surrealism and contemporary art, considering them as practical examples of the use of the technique of Strangeness. This theoretical framework is part of the dissertation: " $O$ Estranhamento na arte da Oficina Guaianases" (NOGUEIRA, 2014).

Keywords: Strangeness, Desautomatization, Disquieting, Singularity of the object.

\section{INTRODUÇÃO}

A noção de estranhamento é um fenômeno vago e abrangente, pouco abordado por teóricos e autores, não é um fenômeno exclusivo das artes, porém é bastante utilizado como técnica na literatura, no cinema, no design, na publicidade e nas artes visuais. Assim, o estranhamento está presente no inconsciente das pessoas, em situações de vida no cotidiano e no imaginário coletivo. Por isso, para se ter uma compreensão ampla sobre essa técnica, é preciso transcender a teoria em artes visuais e ir mais a fundo, em outras áreas do conhecimento, como a psicologia e a teoria da 
literatura, em busca de definições e aspectos filosóficos que esclareçam sobre o tema. Logo, compreender a técnica de estranhamento é de fundamental relevância para o estudo no campo artístico, pois se trata de um procedimento padrão, essencial para o entendimento da arte como linguagem. Um dos primeiros teóricos que relataram sobre o conceito de estranhamento, de maneira geral, foi o psicanalista Sigmund Freud (1919), no texto o Inquietante. Neste, o autor explora a questão do estranho analisando obras literárias e situações médicas relatadas. Além do conceito de Freud, também serão abordados neste artigo, os conceitos de Chklovski e Mukarovsky, e alguns exemplos práticos na história da arte do séc. XX.

\section{O INQUIETANTE: FREUD 1919}

A definição do estranho, daquilo que causa angustia e inquietação, abordada por Freud (1919), foi um dos primeiros relatos teóricos sobre esse assunto, e, de acordo com o próprio psicanalista, foi negligenciado pelos demais autores, até então. O que caracteriza a definição de estranhamento de Freud é que ela se refere ao terrível, ao que desperta angustia e horror. Segundo o próprio psicanalista, "O inquietante é aquela espécie de coisa assustadora que remonta ao que é a muito conhecido, ao bastante familiar." (FREUD, 1919, pág. 331). Freud também relaciona situações inquietantes com a questão do novo, na qual afirma que situações novas (não familiares) também se tornam facilmente assustadoras e inquietantes. A partir daí, percebe-se certa complexidade e ambivalência no conceito, pois o mesmo se relaciona diretamente com o familiar e com o não-familiar, essa relação se dá de maneira em que algo para ser considerado estranho: não basta apenas ser novo, precisa conter elementos bem conhecidos (familiares). E. Jentsch, médico citado pelo o autor, se limitou apenas a relacionar o inquietante com o novo e com a incerteza intelectual. De acordo com Jentsch, o inquietante = não-familiar, entretanto para Freud essa equação estava incompleta justamente por não conter os elementos familiares necessários para causar estranhamento.

Entre os vários significados da palavra unheimliche, existe um que se assemelha com o seu oposto heimliche, no qual se podem obter dois significados. $O$ primeiro, aquilo que é familiar; o segundo, aquilo que está oculto. Nesse sentido, Schelling foi além dessas afirmações, e fez uma observação interessante que define bem a relação entre esses significados. Para ele, seria unheimliche "tudo o que deveria permanecer secreto, oculto, mas apareceu” (SCHELIING apud FREUD, 1919, pág. 338). Logo, pode-se concluir que a maneira em que algo bastante familiar pode se tornar algo novo ou estranho é a chave para técnica do estranhamento.

$\mathrm{Na}$ literatura, Freud cita o exemplo da obra O Homem da Areia (Hoffmann, 1815), na qual a personagem Olímpia, uma boneca aparentemente viva, desperta o amor do jovem personagem Nathaniel. A incerteza intelectual causada no leitor é o primeiro exemplo de estranhamento, ocorrendo na incerteza se a boneca está aparentemente viva, além da hesitação se os fatos ocorridos são reais ou delírios do personagem. Tal estratégia tem a intenção de nos colocar na visão do personagem ampliando as características de estranhamento, "O efeito inquietante é fácil e 
frequentemente atingido quando a fronteira entre fantasia e realidade é apagada" (FREUD, 1919, pág. 364).

Sob a ótica psicanalítica, outro fator inquietante é o medo infantil de perder a visão, que também pode ser transportado para a vida adulta. Segundo Freud (1919), essa inquietação tem uma relação com o medo da castração, manifestada em sonhos e fantasias. O supramencionado teórico, também ressalta a inquietação do duplo ou sósia, que seria o surgimento de pessoas que pela aparência igual, sendo consideradas idênticas, possuindo, assim, o mesmo saber, mesmos traços faciais, mesmas atitudes que o eu original. Otto Rank (apud FREUD, 1919) relaciona essa permutação do eu com a crença na alma e o temor da morte, afirmando que a alma imortal foi provavelmente o primeiro duplo do corpo. Outro exemplo de situação de Estranhamento, mais sutil, acontece quando a repetição não deliberada de algum fato torna inquietante o que é aparentemente inofensivo. Para exemplificar, o supramencionado autor cita alguns exemplos. O primeiro deles é quando nos perdemos em uma floresta com névoa, caminhamos buscando uma saída e sempre nos deparamos com o mesmo local ou, então, quando em um ambiente escuro e desconhecido, procuramos o interruptor de luz e sempre nos esbarramos com o mesmo móvel. Esses casos sugerem uma ideia de algo fatal ou inelutável que está para acontecer, quando em uma situação normal seria apenas um acaso. Sobre isso, Mark Twain (apud Freud, 1919) define essa situação como irresistível comicidade.

Mais um exemplo de estranhamento acontece em um relato de um paciente, que sofrera de transtornos obsessivos: ele dizia ter premonições de tragédias que se confirmavam, desejos de morte e previsões futuras que - fatalmente - aconteciam. Há também tipos de inquietações voltadas para as formas de superstições, como o exemplo, do medo do mau-olhado, que acontece quando alguém possui algo valioso e receia a inveja alheia, Freud relaciona esse tipo de inquietação com a onipotência do pensamento. E por fim, Freud cita outros exemplos de situações inquietantes, como a magia e a feitiçaria, a concepção do animismo (preenchimento do mundo com espíritos humanos) e a relação com a morte, que para muitas pessoas são temas de grande estranhamento.

Em síntese, o conceito de estranho formulado por Freud nos ajuda a compreender o estranhamento de um ponto de vista mais sistemático, principalmente por conter alguns exemplos empíricos, como a questão do novo com elementos familiares, a incerteza intelectual, traumas de infância, o medo de castração, a repetição do acaso, superstições, o medo da morte, entre outros. Sob a ótica Psicanalítica, é correto dizer que todo impulso relacionado às emoções se transforma em angustia quando reprimidos, independente da origem desse sentimento. Logo, pode-se concluir que o inquietante é o retorno desse elemento angustiante que retorna algo muito familiar à psique, como Schelling (apud FREUD, 1919, pág. 360) descreve "algo que deveria ser oculto, mas apareceu".

\section{A SINGULARIZARÃO DO OBJETO: CHKLOVSKI 1917}

A teoria do Estranhamento nas artes, de uma maneira geral, tem sua origem na literatura, através do texto "A arte como procedimento" (Chklovski, 1917). Para Olga Guerizoli-Kempinska (2010, p. 64) essa concepção foi o primeiro conceito da teoria 
moderna da literatura. "[...] As traduções múltiplas, o não acabamento conceitual, [...] e a abertura ao uso que excedem ao campo da literatura, [...] são, com efeito, características pertencentes desde o início ao termo estranhamento [...]"; que deve ser considerado o procedimento geral da arte, ou seja, onde houver arte existe certo grau de estranhamento, e que também deve ser compreendido no sentido de "técnica", "artifício" ou "mecanismo", sendo assim, composto pela diversidade de vários outros procedimentos. O Seu caráter vago e fragmentado se dá devido às condições em que o conceito foi concebido de maneira dispersa, em vários artigos escritos pelo jovem autor Viktor Borisovich Chklovski, entre os anos de 1914 e 1922. Crítico literário, escritor e cenógrafo, considerado por muitos o pai do formalismo russo, Chklovski escreveu esse artigo em um tempo em que não havia distinção entre arte e teoria da arte.

Tempo de ruptura dos limites entre arte e vida, traços de solicitações, violentas e contraditórias, de reivindicações extremas da revolução russa, e de exigências de novas formas estéticas da obra de arte. (GUERIZOLIKEMPINSKA, OLGA, 2010, p.64.).

Apesar de já ter refletido a respeito sobre o conceito de "Estranhamento" anteriormente, Chklovski só publica algo a respeito com essa definição no famoso artigo "Arte como procedimento" "Искусство как прием" datado de 1917, no qual o termo aparece em russo como "остранение" (ostranienie), neologismo formado a partir do adjetivo "cmpaнныŭ" (strannyi) e por isso escrito entre aspas. Na tradução mais precisa para o português o termo seria "Estranhamento". Quando transposto de maneira indireta a partir da língua inglesa o termo também ficaria como "Singularização" ou "Desfamiliarização". Quando é traduzido para a língua francesa o termo seria "étrangéification", que traduzido de maneira indireta para o português ficaria como "Desautomatização", principalmente quando se emprega o sentido de superar o automatismo da percepção.

Chklovski afirma que nem sempre procedimentos de arte são criados de maneira poética, mas acabam servindo para a contemplação estética por acaso, logo o objeto pode ser criado como prosaico e percebido como poético, ou criado como poético e percebido como prosaico. Essa afirmação indica que o caráter poético do objeto está relacionado com a nossa percepção, e deixa claro que qualquer obra pode ter conotações de estranhamento mesmo que seja concebida sem essa intenção, tudo vai depender do contexto da obra.

A argumentação de Chklovski é fundamentada a partir das críticas ao ponto de vista de outro autor russo, Aleksander Potebnia. No Caso, Potebnia, e seus seguidores, é defendida a ideia de que a arte é pensar por imagens (POTEBNIA apud CHKLOVSKI, 1917), gerando esse pensamento uma certa economia de energias mentais, pois a imagem possui apenas a função de agrupar os objetos e as suas funções heterogêneas, explicando o desconhecido pelo conhecido. Ou seja, a imagem tem apenas uma finalidade de comunicação e reconhecimento, sendo mais simples daquilo que ela explica e podendo ser compreendida de maneira coletiva. No Entanto, Chklovski (1917) discorda enfaticamente desse ponto de vista, afirmando que o objetivo da imagem não seria facilitar a nossa compreensão, e sim o oposto: criar uma percepção particular, que enfatize os aspectos subjetivos do receptor. Para isso, o autor russo enfatiza a importância da obscuridade da forma, que consiste em ampliar o tempo e a dificuldade de percepção do objeto de arte. Ele também afirma que, analisando as leis 
gerais da percepção, fica evidente que uma vez tornada habituais, as ações tornam-se também automáticas, dessa maneira os nossos hábitos se tornam automáticos e inconscientes.

Os que podem recordar a sensação que tiveram quando seguraram pela primeira vez a caneta na mão ou quando falaram pela primeira vez uma língua estrangeira e que podem comparar esta sensação com a que sentem fazendo a mesma coisa pela milésima vez, concordarão conosco. (CHKLOVSKI, 1917, pág. 44).

Tolstoi, bastante citado por Chklovski para exemplificar procedimentos de estranhamento na literatura é bastante objetivo quando diz que "[...] se toda a vida complexa de muita gente se desenrola inconscientemente, então é como se esta vida não tivesse sido." (TOLSTOI, 1897, Apud CHKLOVSKI, 1917, pág. 44). A partir dessas elucidações sobre o automatismo, Chklovski (1917) descreve o procedimento-chave para se entender o conceito de estranhamento, a Singularização do Objeto.

E eis que para devolver a sensação de vida, para sentir os objetos, para provar que pedra é pedra, existe o que chama arte. O objetivo da arte é dar a sensação do objeto como visão e não como reconhecimento, o procedimento da arte é o procedimento da singularização dos objetos é o procedimento que consiste em obscurecer a forma, aumentar a dificuldade e a duração da percepção. (CHKLOVSKI, 1917, pág. 45).

Chklovski ainda diz que o ato de percepção em arte é um fim em si mesmo e deve ser prolongado ao máximo, a fim de fazer com que os objetos em arte muitas vezes percebidos como um simples reconhecimento sejam, de fato, percebidos como visão de uma expressão, o que caracteriza o teor poético da obra de arte. Para isso acontecer, o autor russo sugere que seja realizada a liberação do automatismo desse objeto, que se dá de diferentes meios.

Toda arte, à medida, que evolui, procura dificultar cada vez mais a tarefa a ser realizada pelos olhos, ou seja, uma vez solucionado o problema da representação clara, é natural que a forma da imagem se complique e que o espectador, para quem a simplicidade tornou-se demasiado transparente, encontre prazer em solucionar uma tarefa mais complicada. (WOLFFLIN, 1922, p. 269).

Jan Mukarovsky (1967), teórico e crítico literário, checo, complementa o conceito de Chklovski (1917). Para isso, ele sistematiza o sistema linguístico em dois gêneros, linguagem padrão e linguagem poética. As relações que se dão entre esses dois gêneros apresentam dois pontos de vista: o primeiro pela visão do poeta, e o segundo pela visão dos estudiosos da linguagem padrão. A função da linguagem poética é a desautomatização, ou seja, a atualização, o contrário da automatização citada anteriormente, "a mais completa participação da consciência na realização de um ato" (MUKAROVSKI, 1967). A função da linguagem padrão, na sua forma mais pura, tende a evitar a atualização, sua finalidade é atrair a atenção do leitor para comunicação. A relação que se dá entre ambos os gêneros pode ser vista como a segunda, a linguagem padrão, servindo de pano de fundo à primeira, a linguagem poética, na qual, se reflete a deformidade esteticamente intencional das normas linguísticas. Quanto mais fixas e rígidas são as normas de um idioma, maiores são as possibilidades em transgredi-las, sem essa possibilidade a poesia não existiria. Logo, 
É evidente que essas deformidades a norma padrão é a poesia, a poesia não pode existir sem ela, considerar como defeito os desvios à norma da linguagem-padrão, principalmente na época atual que tende para uma forte atualização das componentes lingüísticas é negar fortemente a poesia. (MUKAROVSKI, 1967).

Para se obter uma máxima atualização, não se pode atualizar todas as componentes da linguagem, quando se destaca apenas uma componente, ela se destaca de um plano de fundo da linguagem padrão. Por isso, se todas as componentes fossem atualizadas não existiria um plano de fundo, logo todas as componentes estariam no mesmo nível, o que resultaria em uma nova automatização. No entanto, todas as componentes atualizadas ou não, são avaliadas pela componente dominante, esta põe em movimento e coordena a ação, ela também determina a unidade da obra poética, mas essa é uma unidade sui generis cujo caráter costuma ser designado na estética como unidade dinâmica, no qual percebemos ao mesmo tempo harmonia e desarmonia, convergência (dada pela orientação com a componente dominante) e divergência (dada pela oposição do fundo móvel das componentes não atualizadas). O conceito de Singularização do Objeto (CHKLOVSKI, 1917) se assemelha ao conceito de Atualização (MUKAROVSKY, 1967). Ambos os conceitos têm a finalidade de desautomatizar o leitor, através de deformidades em uma linguagem padrão. "A imagem poética é um dos meios de criar uma impressão máxima, é igual a procedimentos da língua poética, como por exemplo, figuras de linguagem" (CHKLOVSKI, 1917, pág. 42).

\section{O ESTRANHAMENTO NAS ARTES VISUAIS}

Analisando a história da arte de maneira linear, podemos afirmar que o período histórico das vanguardas artísticas no início do Séc. XX foi o momento de maior ruptura com um modelo de representação pictórica tradicional, modelo que até então vinha sido dominante no mundo ocidental, desde o classicismo. Consequentemente, a era moderna, em síntese, é sinônimo de superação a esse modelo. Uma verdadeira crise da mimesis, que ampliou a possibilidade de criação e subjetividade dos artistas, libertando-os das visões platônicas e aristotélicas, verdadeiros cânones ocidentais, consideradas pelos contemporâneos do período como modelos limitadores, dogmáticos e preconceituosos de representação.

A linguagem estava pronta a liberta-se da representação, e a partir daí, o signo deixava de se comunicar sem suspeitar de si. Esta suspeita lançava-se também sobre o sistema de representação. O signo passava a comunicar não só uma plataforma de ambigüidade e opacidades, de extravio da certeza e da verdade, como se via mergulhado numa auto reflexividade em que a linguagem se tornava problema para si própria. (DIAS, 1964, pág. 102).

Por esse caminho, as vanguardas artísticas fizeram parte de um período histórico no qual se teve campo fértil para o surgimento de várias manifestações estilísticas inovadoras, transformações que negavam, ironizavam, parodiavam e subvertiam o modelo clássico de representação. Esse período, rico em novidades e experimentações, foi ideal para um maior desenvolvimento das técnicas de estranhamento no campo das artes visuais e para as novas reflexões sobre a arte no séc. $X X$. 


\subsection{O ESTRANHAMENTO NO CUBISMO}

O Cubismo foi um dos principais movimentos de vanguarda, com grande contribuição para o pensamento da arte do séc. $X X$, influenciou diretamente os estilos subseqüentes, principalmente devido ao seu caráter de ruptura e preocupação em renovar o sistema de representação pictórica vigente, o que caracterizava o principal centro de interesse cubista. Dessa forma, buscavam superar a perspectiva clássica por um modelo de representação que criava relações e proporções diferentes das acadêmicas e tradicionais. Rupturas, anomalias e dissonâncias que podem ser consideradas como o marco inicial para o surgimento e desenvolvimento dos primeiros processos de estranhamento nas artes visuais do séc. XX. Podemos citar como exemplo a técnica da colagem, posteriormente aperfeiçoada de diversas maneiras em outros estilos.

Havia um interesse cubista em superar o modelo mimético do "quadro janela" do movimento impressionista, alvos das maiores críticas cubistas, ironizados por "serem apenas retina e nada de cérebro" (MICHELI, 1991, pág. 173), ou seja, retratarem o momento presente de maneira imediata, da maneira que se vê. No entanto, para os cubistas era interessante a elaboração intelectual no processo de concepção da obra de arte, também valorizavam um rigor técnico na composição que ressaltasse o subjetivismo do autor/artista, e não apenas retratasse as impressões da natureza de maneira rápida e objetiva, como os impressionistas faziam. Influenciados sobre as recentes pesquisas da ciência, fundamentalmente no campo da matemática e da geometria, os cubistas criavam uma nova maneira de conceber a arte, uma nova dimensão do espaço pictórico, que de acordo com MICHELI, (1991, pág. 182) "excluía a ideia de espaço material, em favor de um espaço evocativo, verdadeiro e não ilusório". Essa nova maneira de ver a arte incluía uma quarta dimensão: o tempo; a fim de representar a duração, a verdadeira essência do objeto.

Os objetos podiam se abrir, estender-se, sobrepor-se, subvertendo as regras da imitação e permitindo ao artista uma nova criação do mundo segundo as leis de um critério intelectual particular. (MICHELI, 1991, pág. 182).

Pouco antes da I Guerra Mundial, surge a colagem no cubismo, entre seus principais atores e inventores estão: Picasso (1881-1973) e Braque (1882-1963). A colagem pode ser considerada um marco na história da arte, momento emblematicamente revolucionário, por ser o surgimento de um procedimento que influenciou a arte que foi realizada posteriormente, se aparentando com os readymades de Duchamp, por agregar valor artístico a elementos extra-pictoricos recolhidos no cotidiano. A intenção cubista em relação à colagem tinha objetivos estéticos e intelectuais, buscava valorizar o momento presente, o próprio gesto que fez a colagem, a fim de trazer a realidade do material, com sua textura e materialidade, para compor, dessa forma, a unidade da obra, buscando uma percepção sobre a superficialidade do quadro anti-ilusionista, uma afirmação da realidade.

O estranhamento no cubismo se relaciona com o novo, novidade que está diretamente relacionada com a representação pictórica (as várias perspectivas sobrepostas) e com a técnica da colagem (elementos extra-pictóricos), esses elementos modificaram e ampliaram as possibilidades de arte a serem criadas posteriormente. 


\subsection{O ESTRANHAMENTO NO DADÁ}

Entre todas as vanguardas artísticas, a que mais se apropriou de técnicas de estranhamento foi o Dadá. Originado em Zurique, na Suíça, por volta de 1916, o estilo refletia o estado de espírito dos jovens utopicamente pacifistas, insatisfeitos com o período de indignação e descontentamento que envolvia a primeira guerra mundial .Os Dadaístas Mantinham vivo um desejo de despertar na humanidade um novo olhar sobre o mundo, que testasse as bases dos princípios humanos, colocando em cheque aquilo que seus pais haviam lhes passado, confirmando de fato a "justeza" da veracidade desses tradicionais princípios na prática. Essa era a forma na qual usavam a arte para expressar sua revolta e liberdade.

A impaciência de viver era grande, o desgosto aplicava-se a todas as formas de civilização ditas modernas, às suas próprias bases, à lógica, a linguagem, e a revolta assumia formas em que o grotesco e o absurdo superavam de longe os valores estéticos. (MICHELI, 1991, pág. 131).

O Dadaísmo era uma violenta negação intelectual, negação extrema, questionava os princípios básicos da própria razão, irracionalismo psicológico que já havia se manifestado no expressionismo, porém, no dadaísmo, as proporções eram mais radicais, rejeitava tudo aquilo que estava relacionado com os costumes e as tradições sociais, até mesmo a própria noção de arte. Diferentemente do cubismo, que negava um sistema de representação, o dadá negava a arte como um todo. A obra de arte dadaísta era antes de tudo anti-esteticista, por considerar o esteticismo uma característica burguesa que havia se tornando o principal conteúdo da obra de arte moderna (Autônoma). Devido a isso, segundo (BURGUER, 1974, pág. 105), o dadá pode ser definido como "um ataque ao status da arte na sociedade burguesa.", principalmente devido ao fato central de deslocamento da práxis vital causado por esse esteticismo. Além dessa maneira crítica e destrutiva, o dadá pregava em seu discurso a reintegração da arte a essa práxis vital. Politicamente a tentativa dadaísta de reintegrar a arte a práxis vital falhou, no entanto, contraditoriamente na esfera da arte o dadá causou uma verdadeira revolução estética, sobretudo no que diz respeito da destruição da obra de arte orgânica, ampliando a maneira de como se vê e como fazer arte no séc. XX.

De acordo com Burguer (1974), alguns elementos caracterizam a obra de arte dadaísta, o primeiro deles diz respeito à destruição da obra de ate orgânica, é negada a relação da parte com o todo na obra de arte dadaísta (não orgânica), realizada através da mediação ou até mesmo, em alguns casos, pelo próprio receptor, a composição dadaísta é composta por fragmentos dissonantes independentes entre si, sem uma unidade orgânica pré-estabelecida pelo autor. Outro elemento é a questão do novo, diferentemente da arte moderna onde a novidade se dava em relação à representação (estilos pictóricos que negavam seus antecessores), no dadá essa novidade é mais radical, é uma novidade de ruptura, que nega totalmente toda a tradição de arte, se utilizando do mecanismo do choque para causar estranhamento e desautomatizar o público receptor. Outro elemento presente nas obras dadaísta é o conceito benjaminiano de Alegoria, a obra de arte é composta de fragmentos que não condizem diretamente ao seu contexto de origem podendo ser reinterpretadas em outros contextos com sentidos diferentes. De acordo com Burguer (1974), o conceito de alegoria de benjamim se constitui em três partes: 
1. $\mathrm{O}$ alegorista arranca um elemento à totalidade do contexto da vida. Ele o isola, priva-o de sua função. [...] 2. [...] junta os fragmentos da realidade assim isolados, e através desse processo, cria sentido. 3. Benjamim interpreta a atividade do alegorista como expressão da melancolia. (BURGUER, 1974, p.141).

Outro elemento dadaísta, que também reforça o conceito de alegoria, porém é muito mais específico e provocativo é o conceito de montagem, ele se difere da colagem cubista, pois no cubismo a colagem tem uma função estética, ela integra uma unidade na composição, com equilíbrio entre os elementos. A intenção estética da montagem dadaísta, é muito mais questionadora, foge totalmente das tradicionais regras de julgamento, sendo impossível de ser analisada através dos critérios adotados naquele período. Em síntese a obra de arte dadaísta se constitui por ser uma obra de arte, anti-orgânica que se compõe através da sobreposição de elementos fragmentados da realidade, que assumem sentidos diferentes a cada contexto em que é analisado. Também apresenta certo grau de melancolia e revolta, além de outros elementos que caracterizam a arte vanguardística dadaísta como sendo talvez a mais estranha em relação aos modos de se fazer a arte e também em relação à própria recepção do público.
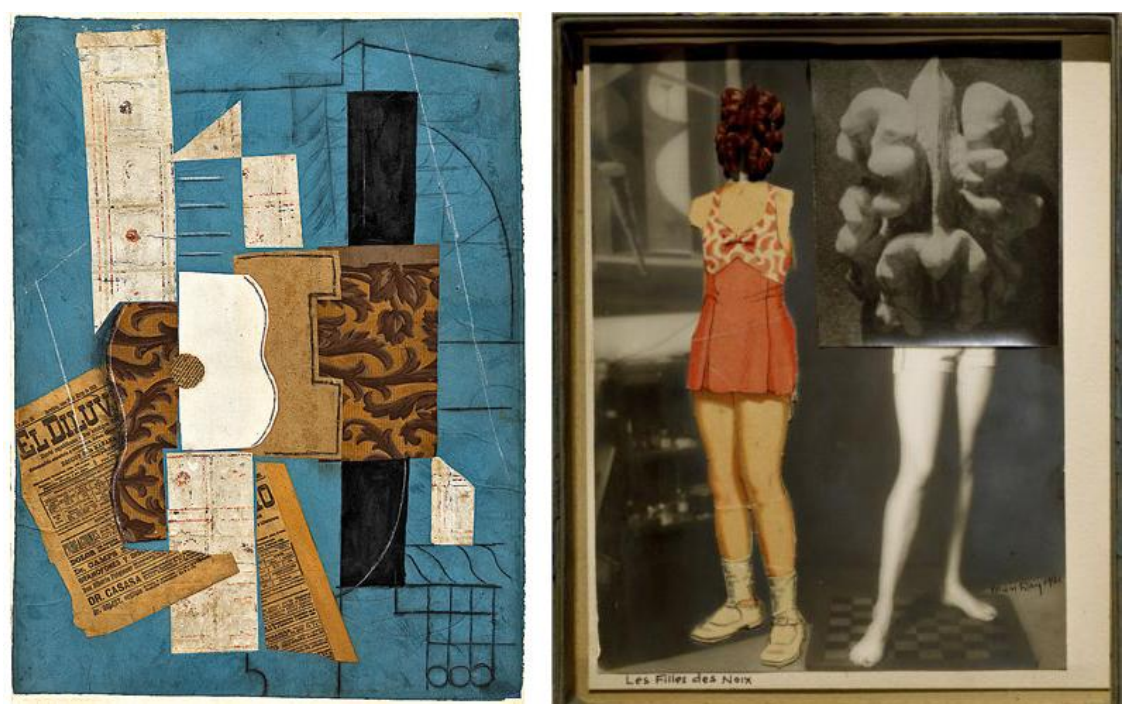

Figura 1 - Guitar - Pablo Picasso, ano 1913 - Colagem Cubista.

Figura 2 - Nut Girls - Man Ray, ano 1941 - Colagem Dadaísta.

Fonte: Google Imagens.

\subsection{O ESTRANHAMENTO NO SURREALISMO}

O emprego da técnica de estranhamento no surrealismo se dá de maneira distinta de outro estilo de vanguarda - o dadá - que, por está inserido em um contexto de pós-guerra, traz em si um sentimento de revolta e descontentamento muito grande. Este sentimento também está presente no surrealismo, mas, de um modo diferentemente do dada, os surrealista buscavam remediar essa crise com uma postura mais construtiva. Assim, "o surrealismo substitui a rejeição total, espontânea, primitiva de dadá pela pesquisa experimental, científica, baseada na filosofia, e na psicologia [...] opõe ao anarquismo puro um sistema de conhecimento". (MICHELI, 
1991, pág. 151, grifos nossos). Para entendermos a relação que se dá do estranhamento com o Surrealismo, é preciso inicialmente uma compreensão sobre o estilo como um todo. Indo por esse caminho, chega-se a André Breton, guia espiritual e criador do manifesto surrealista que tem a melhor definição.

Automatismo psíquico puro pelo qual se pretende exprimir, quer verbalmente, quer por escrito, quer por qualquer outra maneira o funcionamento real do pensamento. Ditado do pensamento, na ausência de qualquer controle exercido pela razão, forma de qualquer preocupação estética ou moral. (BRETON apud MICHELI, 1991, pág. 157).

De um modo geral, o Surrealismo acredita na crença de uma realidade superior de certas formas de associações, antes negligenciadas. Ele afirma que a essência das coisas não está de forma alguma ligada à realidade delas. Por isso busca outras relações que a mente é capaz de entender, que estão presentes na onipotência dos sonhos, no jogo desinteressado do pensamento, no acaso, na ilusão, no fantástico; com o objetivo de resolução dos principais problemas da vida. O sonho representa uma parcela de tempo significativa em nossas vidas, fundamental para a nossa existência. No sonho, o homem se satisfaz plenamente, reconhecendo a sua importância, o surrealismo busca encontrar o ponto de encontro entre sonho e realidade, a fim de devolver ao homem a realidade absoluta, libertando o inconsciente reprimido.

No entanto, o estranhamento no Surrealismo é uma técnica utilizada para subverter as relações das coisas, para precipitar uma crise de consciência geral (principal objetivo) e também para a criação de um mundo fantástico, maravilhoso, em que o homem encontre uma liberdade incondicional e reencontre sua integridade perdida em uma sociedade escrava da lógica convencional. Assim, de acordo com Mario de Micheli (1991), o objeto age como provocador óptico de modo que a imagem surrealista está baseada na dissimilitude, aproximando realidades distintas, violando leis da ordem natural e social, causando um choque violento que coloca, estimula e desperta a imaginação. Max Ernst (1932), descreve metaforicamente o procedimento surrealista de uma maneira bastante didática e sucinta: "Belo como o encontro casual de uma máquina de costura e guarda-chuva sobre uma mesa cirúrgica.". (ERNST, apud MICHELI, 1991, pág. 161.).

\subsection{O ESTRANHAMENTO NA ARTE CONTEMPORÂNEA}

Como citado anteriormente as noções de estranhamento como técnica de arte tem o seu ápice e desenvolvimento a partir do surgimento das vanguardas históricas no começo do séc. XX. Artistas impressionistas, expressionistas, cubistas já criavam uma estética que se baseava nas deformidades da forma para reforçar a impressão poética e subjetiva do autor/artista, mas principalmente os dadaístas e surrealistas, se utilizavam da técnica, como elemento de choque, meio para desautomatizar o público, com intuito de estimular reflexões críticas sobre a sociedade e sobre a instituição de arte. Todas essas críticas e reflexões filosóficas, proveniente da produtiva crise existencial que foram as vanguardas influenciaram diretamente o pensamento da arte atualmente, que tem seu marco inicial na segunda metade do século $X X$, mais precisamente entre os anos 60 e 70 em Nova York, e se opões à arte moderna ou "modernista", se denominando com "Arte Contemporânea". 


\begin{abstract}
Hoje existem muitos nomes para esse ponto de virada - "o fim da arte", "pós-modernismo", "neovanguarda" etc. Para nossos propósitos, também pode ser retratado como o momento no qual a ideia de arte se libertou de uma serie de amarras e distinções, convenções e hábitos que se prendia dos suportes tradicionais da pintura e da escultura e das "habilidades" a eles relacionados; da "produção em estúdio" e das exposições nos assim chamados "cubos brancos"; das divisões que separavam a "alta" arte da arte comercial ou de massa (ou da cultura popular ou vernacular); e daqueles que distinguiam arte e vida cotidiana, ou arte de informação ou documentação e seus "aparatos" de produção e recepção, ou arte e linguagens da critica e da teoria. (RAJCHMAN, 2011)
\end{abstract}

A Arte contemporânea é um movimento artístico que faz pensar, que se apóia numa idéia permanente de busca incessante pelo novo, idéia que transcende o campo da arte, ou até mesmo que questiona o que seria a arte, negando-a e reinventado-a, através da experimentação.
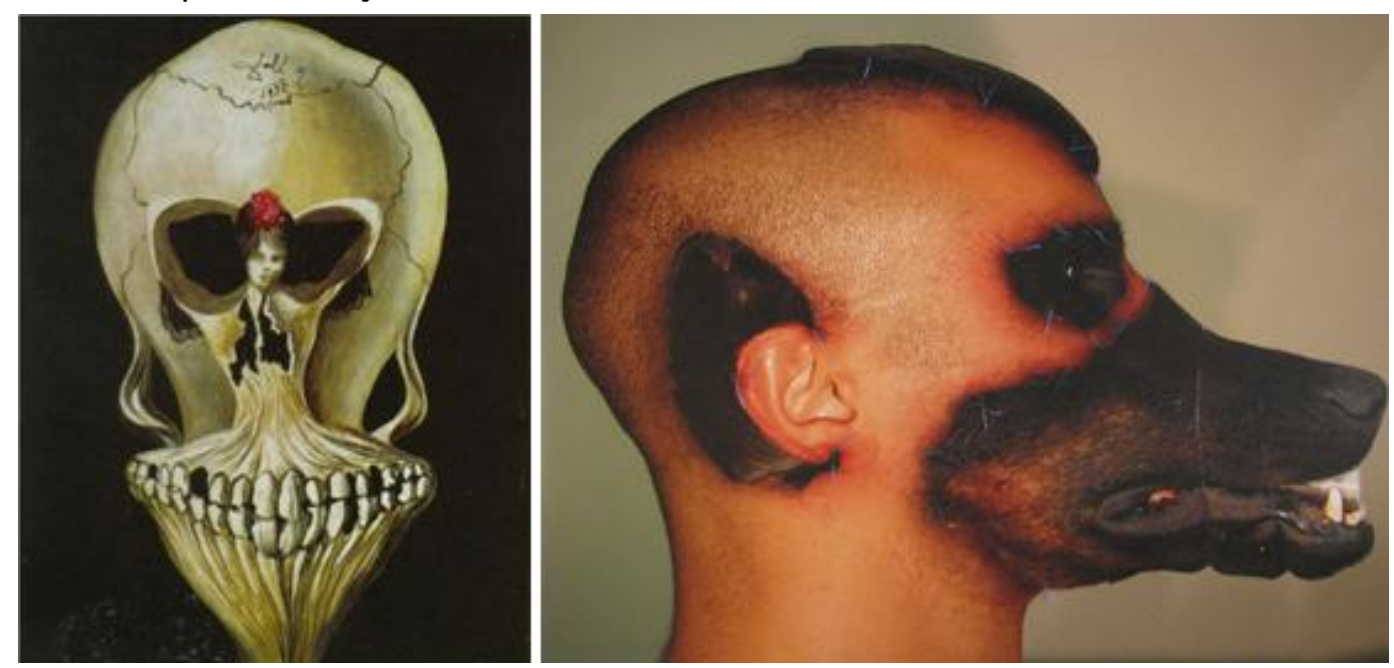

Figura 3 - Ballerina in a Death's Head - Salvador Dali, ano 1939.

Figura 4 - Fantasia de compensação - Rodrigo Braga, ano 2004.

Fonte: Google Imagens

\title{
5. CONCLUSÕES SOBRE A ANÁLISE DO ESTRANHAMENTO
}

Para se ter uma compreensão íntegra sobre a técnica de Estranhamento, é preciso considerar basicamente três fatores determinantes: 0 primeiro diz respeito aos elementos de estranhamento que compõe a obra, esses elementos são universais e estão diretamente associados com os conceitos-chave de estranhamento abordados na pesquisa. Entretanto a presença de tais elementos não garante a estranheza da obra em si. O segundo fator de análise envolve a questão da subjetividade de interpretação do sujeito receptor, está diretamente associado ao seu repertório de imagens e situações, e também a sua experiência de vida, pois o que é "estranho" para uma determinada pessoa pode não ser para outra, esse fator está relacionado diretamente com o "novo" pois quando algo é muito exposto seu caráter de estranhamento é diluído se tornando muitas vezes algo banal e cotidiano para as pessoas. 
Por fim, o terceiro e talvez mais determinante fator, de fundamental relevância em uma análise, diz respeito ao contexto no qual estão inseridos: sujeito e obra, o entorno cultural no qual estão contidos os valores simbólicos presentes no repertório coletivo de determinado grupo ou sociedade. A partir desse contexto é possível identificar o estranhamento em qualquer obra de arte ou até mesmo em uma obra que esteja fora do campo da arte. O estranhamento através do contexto se dá através de uma comparação entre uma situação ou obra com outras situações ou obras que representem a - linguagem padrão - daquele grupo, coletivamente convencionadas; para a partir daí, serem alteradas, deformadas ou até mesmo subvertida.

Todos esses elementos devem ser considerados durante uma análise, caso contrário, a obra mesmo contendo elementos de extrema estranheza pode ser considerada "não estranha", ou até mesmo o inverso, algo aparentemente inofensivo pode ser considerado extremamente estranho, quando analisados a partir de um contexto específico. Concluindo, não podemos afirmar com clareza se determinada obra possui ou não estranhamento sem antes analisar essas três condições.

\section{REFERÊNCIAS}

BÜRGER, Peter. Teoria da vanguarda. Lisboa: Vega, 1993.

CAMARGO, Fernanda M. B. Estranhamento como categoria estética em arte. Espírito Santo: ANPAP, 2010.

CHKLOVSKI, Viktor. A arte como processo. In: TODOROV, Tzvetan. Teoria da LiteraturaI. Lisboa: Edições 70, 1999.

DIAS, Fernando R. A Representação na encruzilhada das vanguardas históricas. Lisboa: Faculdade de Belas Artes CIEBA, 1964.

FREUD, Sigmund. O inquietante. In: FREUD, Sigmund. História de uma neurose Infantil: ("O homem dos lobos"): além do princípio do prazer e outros textos (19171920). São Paulo: Companhia das Letras, 2010.

KEMPINSKA, Olga G. O estranhamento: um exílio repentino da percepção. In: Gragoatá, Niterói, N. 29, 2010.

MARTINS, Luiz R. Colagem: Investigações em torno de uma técnica moderna. São Paulo: ARS, 2007.

MICHELI, Mário de. As vanguardas artísticas. São Paulo: Martins Fontes, 1991.

MUKAROVSKY, J. Standard language and poetic language. In: LEVIN, S., CHATMAN, S. (Ed.) Essays on the language of literature. Boston: Houghton Mifflin Co., 1967.

RAJCHMAN, John. O Pensamento na arte contemporânea. São Paulo: Novos Estudos CEBRAP, N. 91, 2011. 